\title{
Обзор существующих методов технической мелиорации (искусственного изменения свойств горных пород), используемых для уменьшения фильтрационных свойств горных пород
}

\author{
Занаев Ц-Д.С., студент, \\ Технический институт (филиал) \\ Северо-Восточного федерального университета, \\ 2. Нерюнгри
}

\section{Научный руководитель: к.2.-м.н., доцент Рукович А.В.}

В результате применения искусственной мелиорации увеличивается прочность, водонепроницаемость, сопротивление размыву горных пород и др. Техническая мелиорация широко применяется для укрепления откосов выемок дорог и стенок котлованов в водонасыщенных грунтах, при проходке горных выработок, создании противофильтрационных завес и т.д. Для уменьшения фильтрационных свойств горных пород и усиления связей между их частицами применяют методы:
А) цементация
Б) глинизация
В) битумизация
Г) силикатизация
Д) смолизация

Цементация. Сущность этого способа заключается в нагнетании в поры укрепляемого грунта цементного раствора, при отвердевании которого значительно увеличивается прочность и водонепроницаемость горных пород. Способ цементации применим для закрепления грунтов, размеры пор которых обеспечивают свободное проникание частиц цемента. Наибольший эффект получается при цементации крупнообломочных грунтов, крупных и средней крупности песков с коэффициентом фильтрации от 80 до 200 м/сут. Цементация трудноосуществима в мелких песках и совсем непригодна для укрепления илистых, супесчаных, суглинистых и глинистых грунтов. Трещиноватые скальные грунты можно цементировать только при ширине трещин в них более 0,1 мм.

Для цементации применяют цементные или цементно-песчаные растворы состава от 1:1 до 1:3. Раствор нагнетают под давлением 0,3-1 МПа растворонасосами или пневмонагнетателями через предварительно заглубленные трубки-инъекторы диаметром 33-60 мм, имеющие в нижней части отверстия диаметром 4-6 мм. Радиус действия инъекторов ориентировочно принимают для трещиноватых скальных грунтов 1,2-1,5 м, для крупнообломочных грунтов 0,75-1 м, для крупных песков 0,5-0,75 м, для песков средней крупности 0,3-0,5 м.

Расход раствора составляет 20-40\% объема закрепляемого грунта. Упрочнение грунта наступает после схватывания цемента. Закрепленный песчаный грунт вблизи инъектора на 28-е сутки имеет предел прочности на сжатие 2-3 МПа. С изменением радиуса закрепления от 0,4 до 1,2 м предел прочности на сжатие зацементированного песка в крайних слоях меняется от 2 до 0,9 МПа. 
Глинизация служит для уменьшения фильтрационной способности трещиноватых скальных, кавернозных пород и гравелистых грунтов. При этом способе в трещины породы нагнетается под большим давлением глинистая суспензия.

В тех случаях, когда наличие трещин и каверн в породе либо глинистого или иного заполнителя в трещинах делает цементацию ненадежной и слишком дорогой, для заполнения трещин и уменьшения водопроницаемости пород (уплотнение пород) применяют глинизацию. Сущность ее заключается в том, что в трещины породы через специальные буровые скважины нагнетают глинистый раствор. В результате заполнения им трещин и последующего оседания глинистых частиц достигается полная водонепроницаемость породы. Чтобы ускорить оседание глинистых частиц в трещинах и удалить излишнюю воду из жидкого глинистого раствора, к нему прибавляют в качестве коагулянтов хлористый кальций и известь, а для отжима воды увеличивают давление нагнетания. При хорошем качестве работ (плотном заполнении пустот в породе) глинизация является долговечной и не подвержена разрушению агрессивными подземными водами [1].

Техника выполнения работ при глинизации почти такая же, как при цементации. Основные преимущества глинизации перед цементацией - ее меньшая стоимость и возможность использовать местные материалы, а также отсутствие необходимости предварительно промывать трещины и очищать их от глинистого заполнителя.

Наилучшие результаты глинизации дает в трещиноватых горных породах с удельным водопоглощением от 0,1 до 100 л/мин.

Смолизация аналогична глинизации, только гелеобразующей смесью является синтетическая смола и отвердитель, нагнетаемые в грунты. Водный раствор гелеобразующей смеси обладает малой вязкостью, что обеспечивает еe хорошее проникновение в сухие и водонасышенные мелкозернистые грунты с коэффициентом фильтрации от 0,02 до 5 м/сут. Через несколько часов после нагнетания гелеобразующая смесь при взаимодействие с отвердителем превращается в твердеющей гель.

Смолизация придает слабым грунтам значительную прочность, водо- и морозоустойчивость, водопроницаемость, лёссовые грунты после смолизации теряют просадочные свойства, плывуны превращаются в монолитную прочную водоустойчивую породу.

Закрепление грунтов битумом называют битумизацией. Ее применяют для укрепления песков и сильно трещиноватых скальных грунтов. Битумизацию производят нагнетанием в грунт расплавленного битума или холодной битумной эмульсии. Первый способ применим для закрепления сильно трещиноватых скальных грунтов, так как грунт с мелкими порами почти непроницаем для вязкого битума. Разогретый до $200-220{ }^{\circ} \mathrm{C}$ битум нагнетают в грунт инъектором под давлением 2,5-3 МПа. Холодная битумная эмульсия по сравнению с разогретым битумом обладает большей способностью к прониканию в грунт, что позволяет использовать ее для закрепления песков. Для этого приготовляют битумную эмульсию, состоящую из 60\% битума, расщепленного в воде с помощью эмульгатора на мельчайшие взвешенные частицы, и 40\% воды. Полученную эмульсию нагнетают в грунт. Заполняя поры, битумная эмульсия связывает и закрепляет грунт.

Так как суспензия из взвешенных в воде частиц цемента не может проникнуть в грунты с мелкими порами, для закрепления таких грунтов применяют силикатизацию. Известны два способа силикатизации грунтов двухрастворный и однорастворный. 
Сущность двухрастворной силикатизации заключается в образовании связывающего частицы грунта веществагеля кремниевой кислоты - в результате реакции между растворами силиката натрия (жидкого стекла) и хлористого кальция. Эта реакция подобна процессу образования песчаников в природных условиях, но происходит значительно быстрее. Наиболее интенсивно реакция протекает в течение первых двух часов нагнетания раствора в грунт, а затем замедляется. Через 10 сут прочность закрепленного грунта достигает 70-80\% той, которая бывает после завершения процесса - примерно через 90 сут. Двухрастворную силикатизацию применяют для укрепления крупных и средней крупности песков с коэффициентом фильтрации от 2 до 80 м/сут. Радиус закрепления таких песков в зависимости от значения коэффициента фильтрации изменяется от 0,3 до 1 м, а предел прочности закрепленных грунтов на сжатие через 28 суток составляет 1,5-5 МПа.

Однорастворную силикатизацию используют для закрепления мелких песков и плывунов с коэффициентом фильтрации 0,3-5 м/сут. Радиус закрепления таких грунтов 0,3-1 м, а предел прочности на сжатие закрепленных грунтов 0,4-0,5 МПа. Для упрочнения грунтов используют один раствор, состоящий из жидкого стекла и фосфорной кислоты.

Способ закрепления грунтов, представляющий собой дальнейшее развитие метода однорастворной силикатизации и основанный на использовании вместо жидкого стекла раствора синтетической смолы, а взамен фосфорной кислоты соляной, называют смолизацией грунтов. В настоящее время разработана технология закрепления карбамидной смолой песчаных грунтов с коэффициентом фильтрации 0,3-5 м/сут при содержании глинистых частиц не более $2 \%$. Для закрепления грунтов используют водный раствор карбамидной смолы, в который непосредственно перед нагнетанием в грунт добавляют раствор соляной кислоты. Смесь подают в укрепляемый грунт, используя оборудование, применяемое для силикатизации. Процесс отверждения грунтов начинается через 1,5-4 ч после введения раствора соляной кислоты, что необходимо учитывать при производстве работ. Радиус закрепления грунта в зависимости от коэффициента фильтрации изменяется от 0,4 до 0,8 м. Предел прочности укрепленного грунта на одноосное сжатие 1-5 МПа. Вследствие высокой стоимости синтетических смол смолизацию грунтов пока применяют крайне редко, однако это обстоятельство следует рассматривать как временное явление [1].

Список литературы:

1. Скабалланович И.А., Осауленко В.Т.. Гидрогеология, инженерная геология и осушение месторождений. М.: Недра, 1973. 